\title{
Molecular detection and identification of Babesia bovis and Trypanosoma spp. in one-humped camel (Camelus dromedarius) breeds in Egypt
}

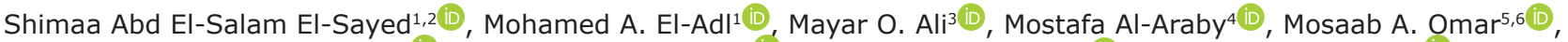

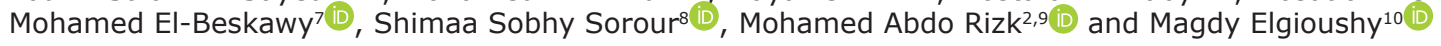

1. Department of Biochemistry and Chemistry of Nutrition, Faculty of Veterinary Medicine, Mansoura University, Mansoura 35516, Egypt; 2. National Research Center for Protozoan Diseases, Obihiro University of Agriculture and Veterinary Medicine, Inada-Cho, Obihiro, Hokkaido, Japan; 3. Department of Animal Genetics, Faculty of Veterinary Medicine, Mansoura University, Mansoura 35516, Egypt; 4. Department of Parasitology, Faculty of Veterinary Medicine, Mansoura University, Mansoura 35516, Egypt; 5. Department of Veterinary Medicine, College of Agriculture and Veterinary Medicine, Qassim University, 51452 Qassim, Saudi Arabia; 6. Department of Parasitology, Faculty of Veterinary Medicine, South Valley University, 83523, Qena, Egypt; 7. Animal Medicine Department (infectious diseases), Faculty of Veterinary Medicine, Matrouh University, Egypt; 8. Department of Parasitology, Faculty of Veterinary Medicine, Kafrelsheikh University, 33516, Kafrelsheikh, Egypt; 9. Department of Internal Medicine and Infectious Diseases, Faculty of Veterinary Medicine, Mansoura University, Mansoura 35516, Egypt; 10. Department of Animal Medicine, Faculty of Veterinary Medicine, Aswan University, Aswan, 37916, Egypt.

Corresponding author: Mohamed Abdo Rizk, e-mail: dr_moh_abdo2008@mans.edu.eg Co-authors: SAEE: abdo_dr_shimaa@yahoo.com, MAE: drmohamedalymaher@hotmail.com,

MOA: mayar.othman132@yahoo.com, MA: alarabyma@yahoo.com, MAO: mos.mohamed@qu.edu.sa, ME: melbeskawy@gmail.com, SSS: shsorour@yahoo.com, ME: gioushymagdy@yahoo.com

Received: 25-10-2020, Accepted: 01-02-2021, Published online: 12-03-2021

doi: www.doi.org/10.14202/vetworld.2021.625-633 How to cite this article: El-Sayed SAE, El-Adl MA, Ali MO, Al-Araby M, Omar MA, El-Beskawy M, Sorour SS, Rizk MA, Elgioushy M (2021) Molecular detection and identification of Babesia bovis and Trypanosoma spp. in one-humped camel (Camelus dromedarius) breeds in Egypt, Veterinary World, 14(3): 625-633.

\begin{abstract}
Background and Aim: Camels are a unique source of milk and meat, which helps recover from several diseases that affect humans worldwide. In Egypt, one of the great obstacles for this industry is tick-borne diseases. This study aimed to characterize blood parasite infections, such as Babesia (B.) bovis and Trypanosoma (T.) spp. in one-humped camel (Camelus dromedarius) $(\mathrm{n}=142)$ breeds in Halayeb and Shalateen, Egypt, through phylogenetic analysis.
\end{abstract}

Materials and methods: The prevalence of B. bovis and Trypanosoma spp. was identified in camels using polymerase chain reaction (PCR) assays targeting the Rhoptry-Associated Protein-1 and internal transcribed spacer 1 genes, respectively. A nested PCR technique was conducted to detect B. bovis. At the same time, KIN multispecies PCR assay was employed to diagnose and classify trypanosome DNA in camels.

Results: B. bovis was detected in 4/142 camels with an infection rate of $2.81 \%$. Sequencing and phylogenetic analyses revealed that the strain of $B$. bovis isolated from this population was closely related to strains isolated from Argentine, the United States, and Brazil. Moreover, Trypanosoma evansi was detected in 8/142 camels with an infection rate of 5.63\%. Sequencing and phylogenetic analyses revealed that this isolated strain T. evansi was closely related to Trypanosoma theileri detected from cattle in Brazil.

Conclusion: The obtained data indicated the existence of B. bovis and T. evansi in camels from two provinces of Egypt. The obtained findings have economic significance and reflect the importance of implementing effective prevention and control methods across Egypt to reduce the incidence of B. bovis and T. evansi in camels.

Keywords: Babesia bovis, camel, Egypt, epidemiology, Trypanosoma spp.

\section{Introduction}

Global concerns about desertification and the resulting loss of biological productivity due to natural processes, climate change, or human activities have highlighted the important role of camels in socioeconomic aspects to protect human populations from health risks and promote species conservation.

Copyright: El-Sayed, et al. Open Access. This article is distributed under the terms of the Creative Commons Attribution 4.0 International License (http://creativecommons.org/licenses/ by/4.0/), which permits unrestricted use, distribution, and reproduction in any medium, provided you give appropriate credit to the original author(s) and the source, provide a link to the Creative Commons license, and indicate if changes were made. The Creative Commons Public Domain Dedication waiver (http:// creativecommons.org/publicdomain/zero/1.0/) applies to the data made available in this article, unless otherwise stated.
Thus, it is critical to implement a proper management system with appropriate disease control measures [1]. In several regions of the world, camels provide an important source of food and milk, which is considered a high protein source with substantial nutritive value. Moreover, the unique survival capability of camels in adverse environmental conditions permits breeders to adopt semi-intensive farming systems for camel production [2]. It was thought that camels are resistant to various pathogenic diseases [3]. Recently, different literatures have described the susceptibility of camels to large number of pathogenic agents, such as bacteria, fungi, parasites, and viruses [4].

In Egypt, vector-transmitted diseases cause various clinical manifestations in farm animals [3]. Members 
of piroplasms have been found in several species of equines, cattle, and camel in Egypt, where specific DNA fragments of those piroplasms were detected in the bloodstream of apparently healthy camels of Babesia and Theileria species [4]. One well-known piroplasm is Babesia spp., which infects humans through tick infestation [5]. Camel babesiosis is an acute to chronic infectious disease that is distributed all over the world [2]. The disease is responsible for deteriorative effects, high morbidity, and substantial economic losses due to transmission through tick-borne hemoparasitic protozoa $[2,4]$. Trypanosoma evansi is a well-known parasite that affects animals and is transmitted mechanically by tabanid species. T. evansi infections cause weight loss, anemia, and abortion in populations spanning several regions of the world, such as South America, Asia, and Africa [6]. In certain cases of trypanosomiasis, subclinical cases and other chronic infections can be found in hosts infected by low virulence strains [7].

Veterinary epidemiology offers the means to investigate disease outbreaks by tracking and monitoring diseases, identifying disease risk factors, implementing herd health programs, and developing biosecurity measures [8]. Accumulating epidemiological knowledge will lead to innovative strategies and clinical techniques that will result in the reduction, prevention, and eradication of important infectious diseases in animals as blood parasitic infections [9]. In this regard, a molecular technique using a polymerase chain reaction (PCR) assay with sequencing analysis can identify blood parasites in epidemiological studies with higher accuracy than other traditionally diagnostic methods, such as microscopic examination of Giemsastained blood smear and enzyme-linked immunoassay (ELISA) tests [3]. The latter two diagnostic tests (microscopy and ELISA) have low sensitivity against chronic and subclinical infections [10], with a lack of specificity in distinguishing between recent and old infections [7]. Most previous methods for epidemiological screening of blood parasite in camels that were performed in Egypt [11-14] used ELISA, the microscopy method, or PCR without performing sequencing and phylogenetic analysis for the diagnosis of parasites. Moreover, most of the previous studies screened only one blood parasite. For the last few years, most of the camels imported to Egypt came from Sudan. Identification and phylogenetic analysis of blood parasites in camels raised on the border between Egypt and Sudan are of great economic importance.

Therefore, this study aimed to use molecular diagnostic techniques to detect parasitic blood infections (Babesia bovis and Trypanosoma spp.) in camel breeds in Halayeb and Shalateen in Egypt followed by phylogenetic analysis to identify each parasite.

\section{Materials and Methods}

\section{Ethical approval and informed consent}

In this study, all experimental protocols were approved by the Animal Care and Use Committee,
Faculty of Veterinary Medicine, Mansoura University, Egypt. According to the Egyptian Medical Research Ethics Committee (No. 14-126), all Institutional and National Guidelines for the care and use of animals were followed. All experiments were carried out under the authority of the Ministry of Education, Egypt, in compliance with the Fundamental Guidelines for Proper Conduct of Animal Experiment and Related Activities in Academic Research Institutions. Informed written consent was obtained from the owner.

\section{Study period and location}

The screened blood samples were collected during July 2017 from one-humped camels reared in Halayeb and Shalateen in Egypt, at the Sudan border. The samples were processed at Faculty of Veterinary Medicine, Mansoura University, Egypt.

\section{Sampling}

One hundred and forty two blood samples were collected from one-humped camels reared in Halayeb and Shalateen in Egypt, at the Sudan border (Figure-1). All obtained blood samples were tested for infection with B. bovis and Trypanosoma spp. During the sampling period, all animals were apparently healthy.

DNA extraction and PCR detection of hemoparasites

Blood samples were collected from the jugular veins of camels selected for our study. Approximately $2 \mathrm{~mL}$ whole blood was collected from each animal in a Vacutainer tube containing ethylenediaminetetraacetic acid (EDTA). The blood samples were labeled and stored at $-20^{\circ} \mathrm{C}$ until DNA extractions were conducted. The DNA samples were extracted from $300 \mu \mathrm{L}$ blood samples using a commercial kit (Promega, Madison, WI, USA), following the manufacturer's instructions, and then stored at $-20^{\circ} \mathrm{C}$ until further use. B. bovis and Trypanosoma spp. were detected in DNA samples using a previously described diagnostic PCR assay

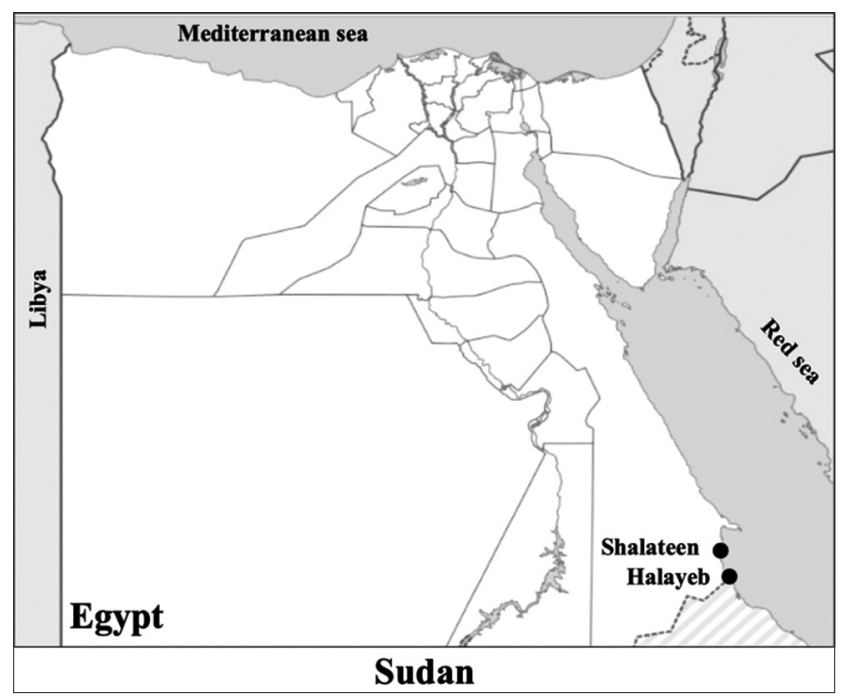

Figure-1: Map of the study sites of the blood parasites molecular epidemiology study in Egypt. Blood samples were collected from animals reared in Halayeb and Shalateen as indicated by bullet points [Source: https://simplemaps. com/resources/svg-eg]. 
targeting Rhoptry-Associated Protein-1 (RAP-1) and internal transcribed spacer 1 (ITS1) genes, respectively [15-17]. Nested PCR assays were used for the detection of $B$. bovis. KIN multispecies PCR reaction was employed to detect and identify trypanosome DNA in camels. A KIN multispecies PCR amplifies ITS1 and simultaneously detects three major trypanosome species: T. evansi, Trypanosoma congolense, and Trypanosoma vivax [16]. Primer sequences and annealing temperatures are shown in Table-1. Enzyme activation and denaturation used for the amplification conditions for $B$. bovis and Trypanosoma spp. were $95^{\circ} \mathrm{C}$ for $3 \mathrm{~min}$ and $95^{\circ} \mathrm{C}$ for $30 \mathrm{~s}, 95^{\circ} \mathrm{C}$ for $5 \mathrm{~min}$ and $95^{\circ} \mathrm{C}$ for $30 \mathrm{~s}$, and $94^{\circ} \mathrm{C}$ for $3 \mathrm{~min}$ and $94^{\circ} \mathrm{C}$ for $1 \mathrm{~min}$, respectively [15-17]. After the product was chilled to $4^{\circ} \mathrm{C}$, gel electrophoresis of the PCR products was performed on $1.5 \%$ agarose gel with Tris/Borate/EDTA buffer and was stained with ethidium bromide. The final PCR product was then visualized under ultraviolet light.

\section{Cloning and sequencing of PCR products}

Extraction of amplicons of PCR samples with high band intensities using a QIAquick Gel Extraction Kit (QIAGEN, Hilden, Germany) was conducted from agarose gels. The samples were then cloned into a plasmid vector (PCR 2.1-TOPO, Invitrogen, Carlsbad, CA, USA). A genetic analyzer AB1 PRISM 100 (Applied Biosystems, Foster City, CA, USA) was used to sequence two colonies for each amplicon.

\section{Phylogenic analysis}

The evolutionary history was predicted using the neighbor-joining method [18]. The optimal tree with a sum of 3-branch length $=56.08480007$ is shown. The percentage of replicate trees in which associated taxa clustered together in the bootstrap test (1000 replicates) is shown next to the branches [19]. Evolutionary distances were computed using the maximum composite likelihood method [20] and are represented by the units of the number of base substitutions per site. The analysis involved 17 nucleotide sequences. The codon positions were $1^{\text {st }}+2^{\text {nd }}+3^{\text {rd }}+$ Noncoding. All positions containing gaps and missing data were eliminated. There were 201 positions in the final dataset. Evolutionary analyses were conducted using MEGA6 [20].

\section{Statistical analysis}

The Open Epi program was used to detect the upper and lower limits of the confidence intervals of the positive rates for B. bovis and T. evansi parasites (http:// www.openepi.com/v37/Proportion/Proportion.htm).

\section{Results}

The genomic DNA sequences of the detected blood parasites in camel blood were subjected to PCR with universal primers to detect all possible strains of Babesia and Trypanosoma species to amplify small ribosomal subunits in those parasites using a molecular diagnostic approach. The infection rates for $B$. bovis and T. evansi were $2.81 \%$ and $5.63 \%$, respectively (Table- 2 ). Species-specific PCR assays detected B. bovis and KIN multispecies, while the PCR detected Trypanosoma species in the camel populations (Supplementary Figure-1). One sample harbored mixed infections from Babesia and Trypanosoma parasite species.

The nucleotide sequences of PCR amplified RAP-1 and ss-rRNA genes of Babesia species and the ITS1 gene of Trypanosoma species determined in this study have been registered and were assigned the following GenBank accession numbers: B. bovis (MF737083.1) and T. evansi (MF737081.1). For phylogenetic analysis, nucleotide sequences of the target genes from other species of Babesia and Trypanosoma were included for comparison (Tables-S1 and S2).

Detection of $B$. bovis in camel blood was determined using primer pairs flanking $R A P-1$. PCR of $R A P-1$ produced an amplicon size of 298 bp that was evaluated by GenBank for further confirmation of the determined sequence. The confirmed sequence was deposited in GenBank under accession number MF737083.1, where a similarity index test among other related $B$. bovis species was conducted using GenBank. A phylogenetic analysis was constructed using our obtained species and other related sequences of the RAP-1 gene in $B$. bovis. The phylogenetic analysis revealed a significant decrease in genetic distance between our obtained species and other species isolated from Argentina (AF030056), the United States (AF030054), and Brazil (KC964615) (Figure-2). Interspecies genetic distance analysis was conducted between our obtained $R A P-1$ gene sequences and sequences of related taxa, and a close genetic distance was detected between our isolated strain and other taxa isolated from cattle in Argentina (AF030056.2) and the United States (AF030054.1) (Supplementary Figure-2). For further confirmation, an amino acid sequence was deduced from our obtained sequence and was aligned with other

Table-1: Primary and nested PCR primers used for PCR amplifications.

\begin{tabular}{|c|c|c|c|c|c|c|c|}
\hline Species & Assay & Primer sequence $\left(5^{\prime} \rightarrow 3^{\prime}\right)$ & Annealing & $\begin{array}{l}\text { Amplification } \\
\text { cycles (No.) }\end{array}$ & $\begin{array}{l}\text { Product } \\
\text { size }\end{array}$ & $\begin{array}{c}\text { Target } \\
\text { gene }\end{array}$ & References \\
\hline \multirow[t]{2}{*}{ B. bovis } & PCR & $\begin{array}{l}\text { F-CACGAGCAAGGAACTACCGATGTTGA } \\
\text { R- CCAAGGACCTTCAACGTACGAGGTCA }\end{array}$ & $55^{\circ} \mathrm{C}$ & 45 & $360 \mathrm{bp}$ & $R A P-1$ & {$[15-17]$} \\
\hline & $\mathrm{nPCR}$ & $\begin{array}{l}\text { F- TCAACAACGTACTCTATATGGCTACC } \\
\text { R- CTACCGACCAGAACCTTCTTCACCAT }\end{array}$ & $55^{\circ} \mathrm{C}$ & 35 & 298 bp & & \\
\hline $\begin{array}{l}\text { Trypanosoma } \\
\text { spp. }\end{array}$ & KIN-PCR & $\begin{array}{l}\text { F- GCGTTCAAAGATTGGGCAAT } \\
\text { R- CGCCCGAAAGTTCACC }\end{array}$ & $60^{\circ} \mathrm{C}$ & 40 & $540 \mathrm{bp}$ & ITS1 & {$[16]$} \\
\hline
\end{tabular}

B. bovis: Babesia bovis, $\mathrm{PCR}=$ Polymerase chain reaction, RAP-1=Rhoptry-Associated Protein-1, ITS1=Internal transcribed spacer 1 
related sequences of $R A P-1$ protein (Supplementary Figure-2). The results of the phylogenetic analysis of proteins showed a close genetic relationship with other strains from Mexico (AAC27387.1) (Figure-3). Pairwise genetic distance was performed between our obtained amino acid sequence and sequences of related species of $R A P-1$ genes, and close relationships with all aligned species except the isolated species from Brazilian bovine species (AFQ30755.1) were revealed (Supplementary Figure-3).

Internal transcript spacer 1 was used for simultaneous identification of three major trypanosome species ( $T$. evansi, T. congolense, and T. vivax) in camels reared in Upper Egypt, with a product size of $540 \mathrm{bp}$ using a KIN multispecies PCR assay. The sequencing results indicated that T. evansi is the causative agent of trypanosomosis in the camels under study. An accession number was deposited in GenBank for our obtained sequence (MF737081) (Figure-4). A phylogenetic tree was constructed depicting our isolated species of $T$. evansi and with related species where a higher similarity index was aligned with our sequence, and a lower genetic distance was observed between our isolated sequence and Trypanosoma theileri isolated from cattle in Brazil. The phylogenetic analysis revealed the presence of two clades (mammalian

Table-2: PCR detection of blood parasites in camels.

\begin{tabular}{lcc}
\hline Species & Positive No. & \% CI \\
\hline B. bovis & 4 & $2.81(1.10-7.01)$ \\
T. evansi & 8 & $5.63(2.88-10.72)$ \\
\hline
\end{tabular}

a $95 \%$ confidence interval, B. bovis: Babesia bovis, $\mathrm{PCR}=$ Polymerase chain reaction, $T$. evansi=Trypanosoma evansi and non-mammalian), wherein T. evansi clustered with the mammalian group (Figure-4). Genetic distance analysis of our isolated T. evansi and other related trypanosome species revealed close genetic distance with AY0433156.1 from the United Kingdom in bank vole, AY043355.1 from the United Kingdom in wood mouse, and AY043354.1 from the United Kingdom in field vole with a 0.69 value in comparison with other included taxa (Supplementary Figure-4).

\section{Discussion}

A phylogenetic analysis was designed for our isolated sequence and other sequences with a high similarity index using the neighbor-joining method for statistical and phylogenetic analysis of 500 replicates. A close genetic relationship was observed between our strain and other strains from Argentina, the United States, and Brazil. A similar result was investigated through research conducted by Mtshali et al. [21] who found that a nested PCR technique to amplify $R A P-1$ revealed a close genetic relationship of a South African strain of $B$. bovis strains with other strains from Uruguay, Argentina, Brazil, and the United States. However, the presence of polymorphism can adequately discriminate between two species [22]. Similarly, the conservation of Babesia spp. sequence among species was observed among Brazilian strains of B. bovis (98-100\%) [23].

Three main trypanosome species ( $T$. evansi, $T$. congolense, and T. vivax) can be simultaneously detected in the circulating blood of camels using internal transcript spacer 1. A genetic relationship between our isolated species and other Trypanosoma species has been established through phylogenetic analysis.

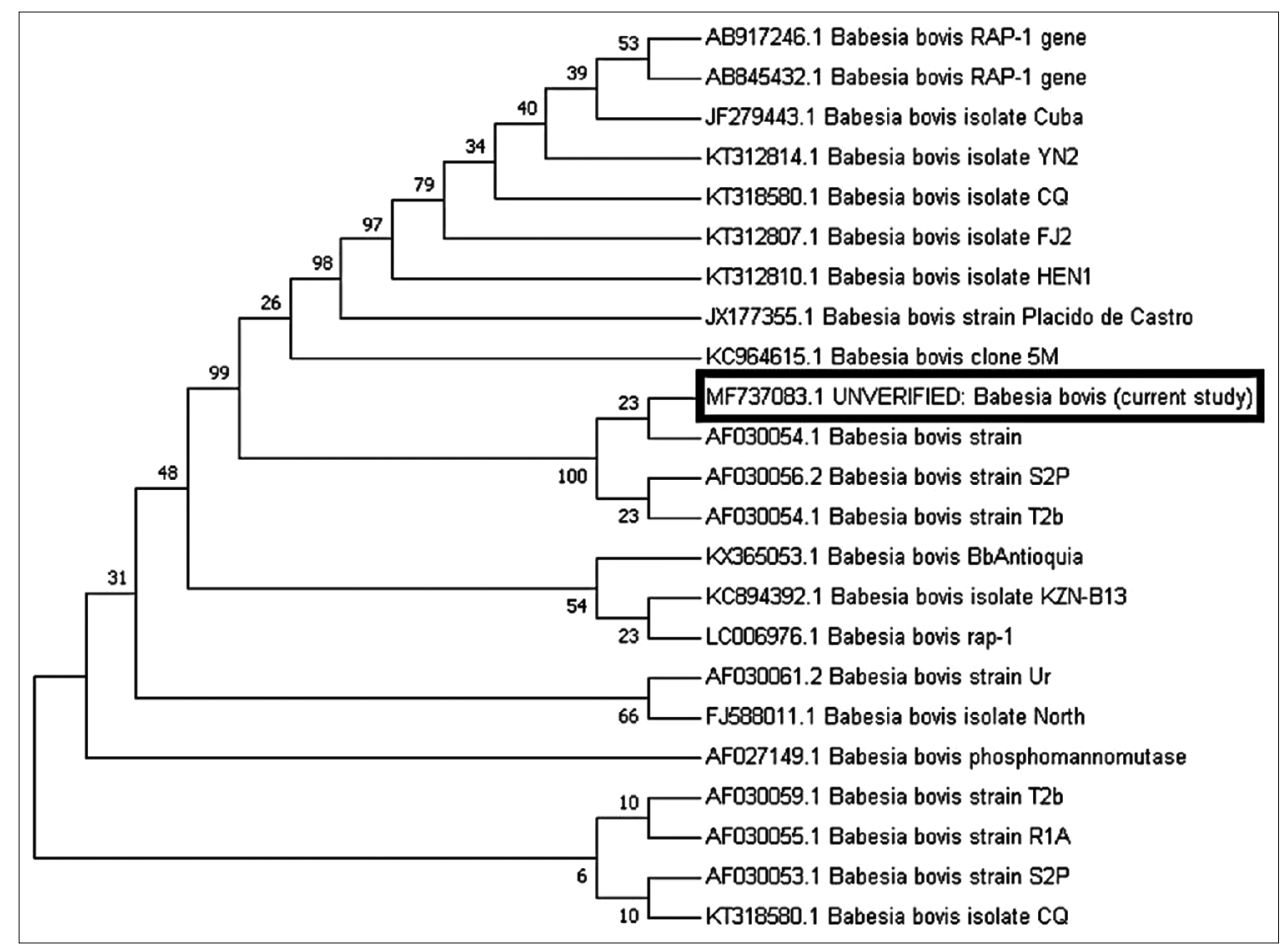

Figure-2: Phylogenic tree of Babesia bovis Rhoptry-Associated Protein-1 gene. The nucleotide sequences determined in this study are shown in boldface type letters. Bootstrap values are provided at the beginning of each branch. The sequence identified from Egypt in this study is boxed in black. 


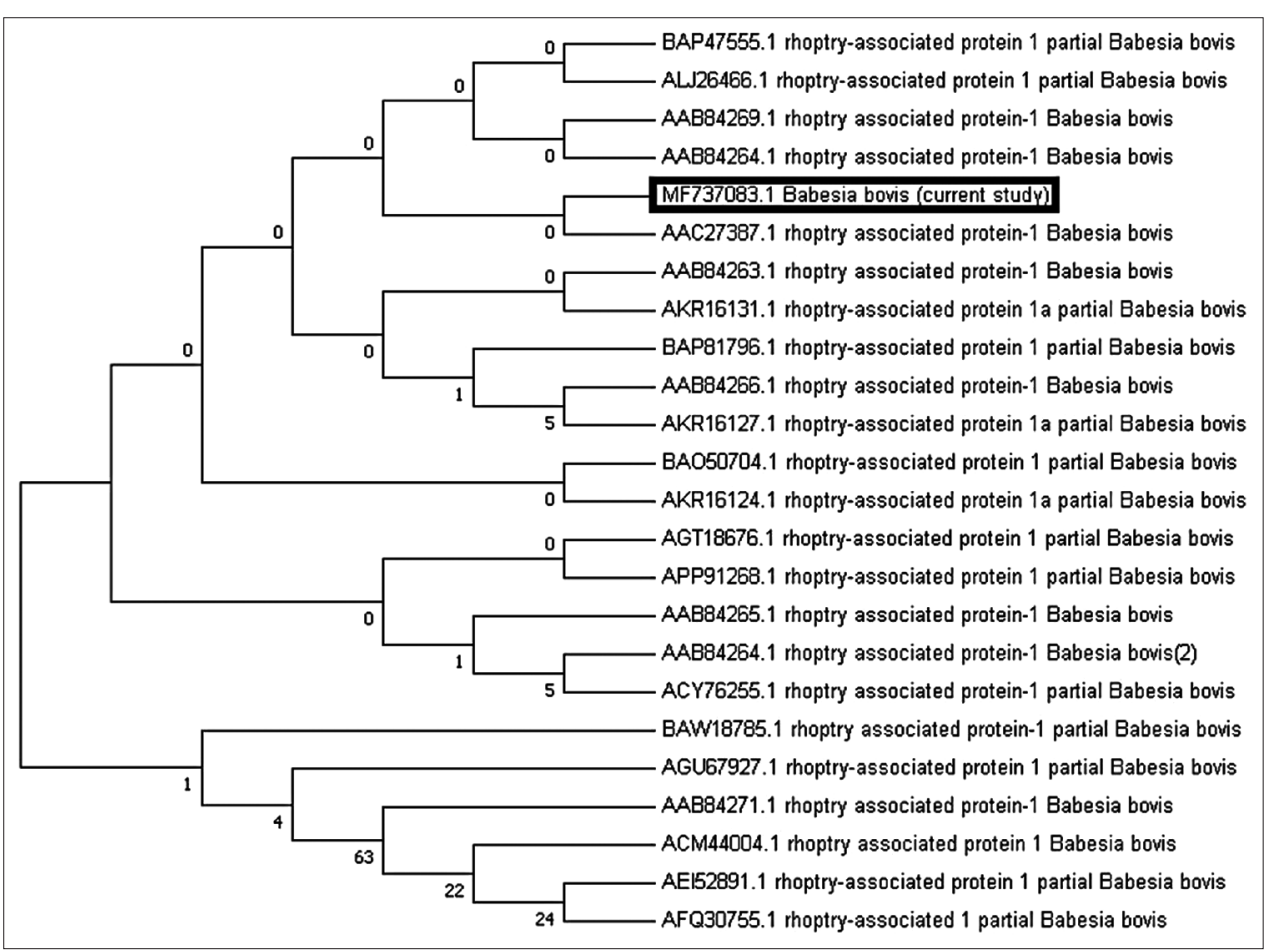

Figure-3: Protein's phylogenetic tree of Babesia bovis Rhoptry-Associated Protein-1 gene. The amino acids sequences determined in this study are shown in boldface type letters. Bootstrap values are provided at the beginning of each branch. The sequence identified from Egypt in this study is boxed in black.

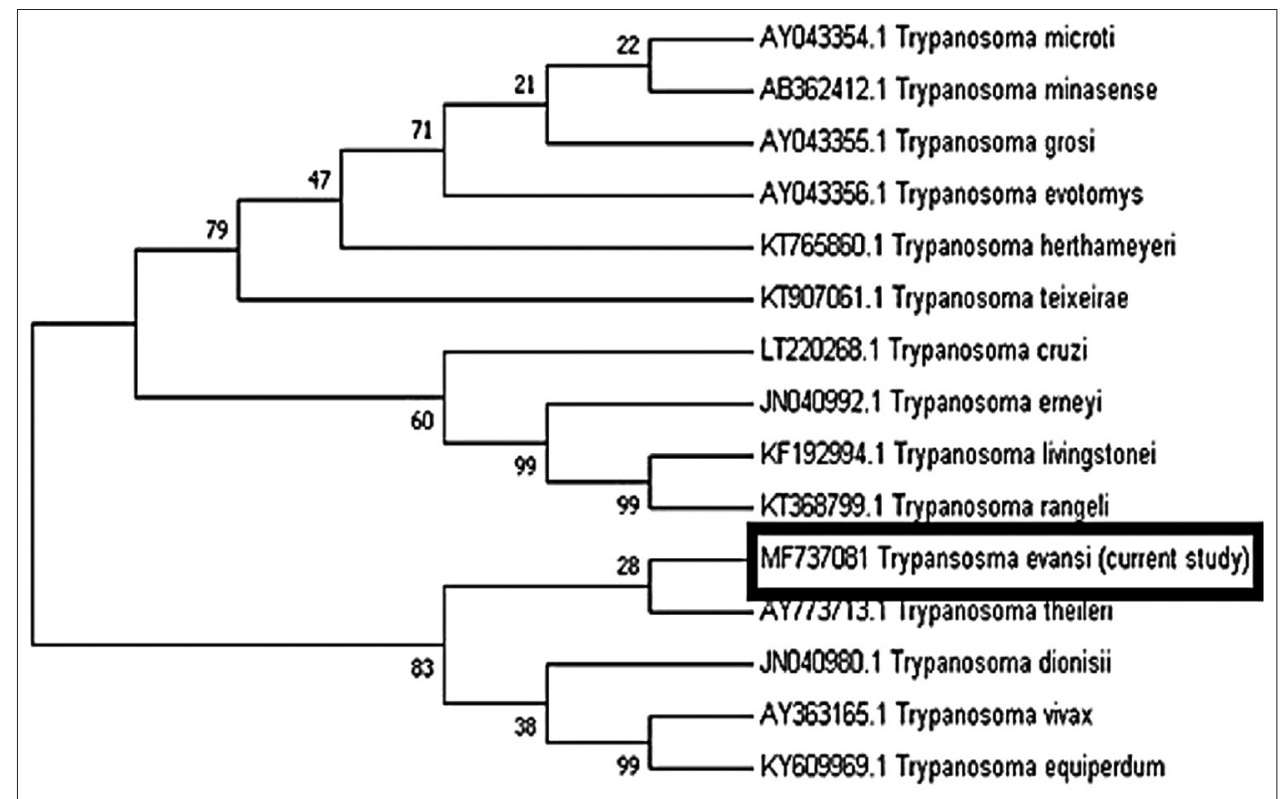

Figure-4: Phylogenic tree of Trypanosoma evansi internal transcribed spacer 1 gene. The nucleotide sequences determined in this study are shown in boldface type letters. Bootstrap values are provided at the beginning of each branch. The sequence identified from Egypt in this study is boxed in black.

In this study, T. evansi was identified through PCR sequencing and was determined to be closely related to T. theileri detected from cattle in Brazil. Trypanosome was classified into several clades in a study in 1996 by Maslov et al. [24] which are as follows: Mammalian, bird group, and elasmobranch, vertebrates, and invertebrates parasites. Hughes and Piontkivska [25] classified trypanosome species according to the amino acid sequence of a small ribosomal subunit into 42 protein families. They also classified Trypanosoma families according to the host and location into American, and African. In Egypt, internal transcript spacer 1 was used to investigate the phylogenetic relationship among trypanosome species and revealed genetic diversity among those species, which can be used as a diagnostic tool for the identification of trypanosome species [26].

This study has some limitations that should be noted. The small sample size used in this study may not allow for a generalizable conclusion about the incidence rate of different hemoparasites included in the study. 
Moreover, this study was carried out in Upper Egypt, which so further investigation is needed to determine the presence blood parasites in other areas of Egypt.

\section{Conclusion}

The data provided here indicate the presence of B. bovis and T. evansi in camels from two provinces of Egypt. These findings are of economic significance and reflect the importance of adopting successful prevention and control methods across Egypt to reduce the incidence and spread of blood parasite infection in camels.

\section{Authors' Contributions}

SAEE, MAR, MAE, and ME: Conceived and designed the experiments. SAEE, MAR, MAE, MOA, and ME: Performed the experiments. SAEE, MAE, MAO, and ME: Analyzed the data. SAEE, MAR, MAE, MA, ME, ME, and SSS: Contributed reagents/ materials/analysis tools. SAEE, MAR, MAE, and ME: Wrote the manuscript. All authors reviewed the manuscript.

\section{Acknowledgments}

This study is supported by the Ministry of Higher Education of Egypt. The authors would like to thank the owners and staff of the study farms in Egypt.

\section{Data Availability}

All data collected during this study are included in this article.

\section{Competing Interests} interests.

The authors declare that they have no competing

\section{Publisher's Note}

Veterinary World remains neutral with regard to jurisdictional claims in published map and institutional affiliation.

\section{References}

1. Zarrin, M., Riveros, J.L., Ahmadpour, A., de Almeida, A.M., Konuspayeva, G., Vargas-Bello-Pérez, E., Faye, B. and Hernández-Castellano, L.E. (2020) Camelids: New players in the international animal production context. Trop. Anim. Health Prod., 52(3): 903-913.

2. Mihic, T., Rainkie, D., Wilby, K.J. and Pawluk, S.A. (2016) The therapeutic effects of camel milk: A systematic review of animal and human trials. J. Evid. Based Complementary Altern. Med., 21(4): NP110-NP126.

3. Elsify, A., Sivakumar, T., Nayel, M., Salama, A., Elkhtam, A., Rizk, M., Mosaab, O., Sultan, K., Elsayed, S., Igarashi, I. and Yokoyama, N. (2015) An epidemiological survey of bovine Babesia and Theileria parasites in cattle, buffaloes, and sheep in Egypt. Parasitol. Int., 64(1): 79-85.

4. Qablan, M.A., Sloboda, M., Jirku, M., Obornik, M., Dwairi, S., Amr, Z.S., Horin, P., Lukes, J. and Modry, D. (2012) Quest for the piroplasms in camels: Identification of Theileria equi and Babesia caballi in Jordanian dromedaries by PCR. Vet. Parasitol., 186(3-4): 456-460.

5. Rizk, M.A., El-Sayed, S.A.E., Nassif, M., Mosqueda, J., Xuan, X. and Igarashi, I. (2020) Assay methods for in vitro and in vivo anti-Babesia drug efficacy testing: Current progress, outlook, and challenges. Vet. Parasitol., 279(3): 109013.

6. Desquesnes, M., Dargantes, A., Lai, D.H., Lun, Z.R.,
Holzmuller, P. and Jittapalapong, S. (2013) Trypanosoma evansi and surra: A review and perspectives on transmission, epidemiology and control, impact, and zoonotic aspects. Biomed. Res. Int., 2013(9): 321237.

7. Elhaig, M.M., Youssef, A.I. and El-Gayar, A.K. (2013) Molecular and parasitological detection of Trypanosoma evansi in Camels in Ismailia, Egypt. Vet. Parasitol., 198(12): 214-218.

8. Salman, M.D. (2009) The role of veterinary epidemiology in combating infectious animal diseases on a global scale: The impact of training and outreach programs. Prev. Vet. Med., 92(4): 284-287.

9. Smith, R.S. (2005) Veterinary Clinical Epidemiology. CRC Press, Boca Raton.

10. El-Sayed, S., Rizk, M.A., Terkawi, M. and Igarashi, I. (2019) Cocktail Babesia bovis antigens for global detection of Babesia bovis infection in cattle. Exp. Parasitol., 206(9): 107758.

11. Abd-Elmaleck, B.S., Abed, G.H. and Mandourt, A.M. (2014) Some protozoan parasites infecting blood of camels (Camelus dromedarius) at Assiut Locality, Upper Egypt. $J$. Bacteriol. Parasitol., 5(2): 1-7.

12. Barghash,S.M., Darwish, A.M. and El-Naga, T.R.A. (2016) Molecular detection of pathogens in ticks infesting camels in Matrouh Governorate, Egypt. J. Bacteriol. Parasitol., 7(2): 1-7.

13. Haridy, F.M., Khalil, H.H. and Morsy, T.A. (2011) Trypanosoma evansi in dromedary camel: With a case report of zoonosis in greater Cairo, Egypt. J. Egypt Soc. Parasitol., 41(1): 65-76.

14. El-Naga, T.R.A. and Barghash, S.M. (2016) Blood parasites in camels (Camelus dromedarius) in Northern West Coast of Egypt. J. Bacteriol. Parasitol., 7(1): 258.

15. Mtshali, M.S. and Mtshali, P.S. (2013) Molecular diagnosis and phylogenetic analysis of Babesia bigemina and Babesia bovis hemoparasites from cattle in South Africa. BMC Vet. Res., 9(8): 154.

16. Mossaad, E., Salim, B., Suganuma, K., Musinguzi, P., Hassan, M.A., Elamin, E.A., Mohammed, G.E., Bakhiet, A.O., Xuan, X., Satti, R.A. and Inoue, N. (2017) Trypanosoma vivax is the second leading cause of camel trypanosomosis in Sudan after Trypanosoma evansi. Parasit. Vectors, 10(1): 176.

17. Rizk, M.A.,AbouLaila, M., El-Sayed, S.A.E., Guswanto,A., Yokoyama, N. and Igarashi, I. (2018) Inhibitory effects of fluoroquinolone antibiotics on Babesia divergens and Babesia microti, blood parasites of veterinary and zoonotic importance. Infect. Drug Resist., 2018(11): 1605-1615.

18. Saitou, N. and Nei, M. (1987) The neighbor-joining method: A new method for reconstructing phylogenetic trees. Mol. Biol. Evol., 4(4): 406-425.

19. Felsenstein, J. (1985) Confidence limits on phylogenies: An approach using the bootstrap. Evolution, 39(4): 783-791.

20. Tamura, K., Stecher, G., Peterson, D., Filipski, A. and Kumar, S. (2013) MEGA6: Molecular evolutionary genetics analysis Version 6.0. Mol. Biol. Evol., 30(12): 2725-2729.

21. Mtshali, P.S., Tsotetsi, A.M., Thekisoe, M.M. and Mtshali, M.S. (2014) Nested PCR detection and phylogenetic analysis of Babesia bovis and Babesia bigemina in cattle from Peri-urban localities in Gauteng Province, South Africa. J. Vet. Med. Sci., 76(1): 145-150.

22. Fisher, T.G., McElwain, T.F. and Palmer, G.H. (2001) Molecular basis for variable expression of merozoite surface antigen gp45 among American isolates of Babesia bigemina. Infect. Immun., 69(6): 3782-3790.

23. Ramos, C.A., Araújo, F.R., Alves, L.C., de Souza, I.I.F., Guedes, D.S. Jr. and Soares, C.O. (2012) Genetic conservation of potentially immunogenic proteins among Brazilian isolates of Babesia bovis. Vet. Parasitol., 187(3-4): 548-552.

24. Maslov, D.A., Lukes, J., Jirku, M. and Simpson, L. (1996) Phylogeny of trypanosomes as inferred from the small and large subunit rRNAs: Implications for the evolution of parasitism in the trypanosomatid protozoa. Mol. Biochem. Parasitol., 75(2): 197-205. 
25. Hughes, A.L. and Piontkivska, H. (2003) Molecular phylogenetics of Trypanosomatidae: Contrasting results from $18 \mathrm{~S}$ rRNA and protein phylogenies. Kinetoplastid Biol. Dis., 2(1): 15 .
26. Amer, S., Ryu, O., Tada, C., Fukuda, Y., Inoue, N. and Nakai, Y. (2011) Molecular identification and phylogenetic analysis of Trypanosoma evansi from dromedary camels (Camelus dromedarius) in Egypt, a pilot study. Acta Trop., 117(1): 39-46.

\section{Supplementary Figures}

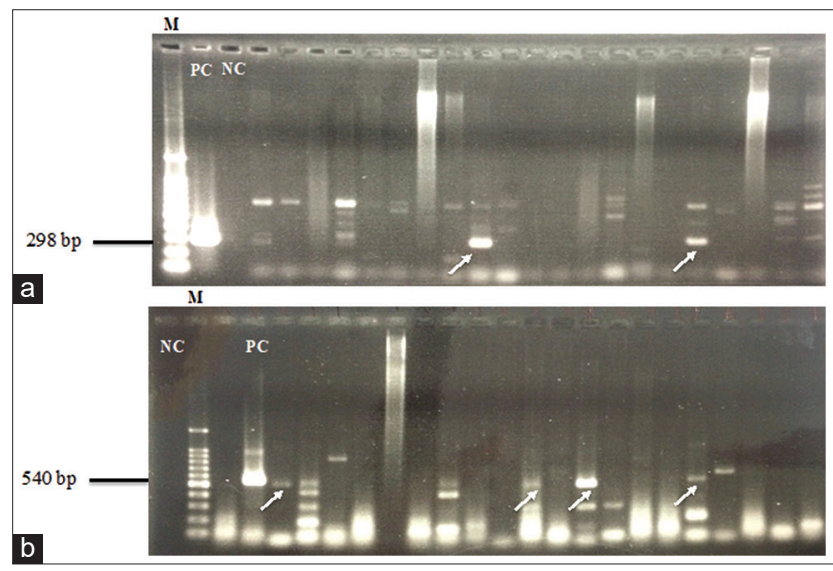

Supplementary Figure-1: Polymerase chain reaction (PCR) detection of surveyed Babesia and Trypanosoma parasites from camel in Egypt. (a) Babesia bovis. (b) Trypanosoma spp. PC: Positive control; NC: Negative control. The expected size of the PCR products was 298 and 540 bp for B. bovis and Trypanosoma spp., respectively. Arrows indicate positive sample.

\begin{tabular}{|c|c|c|c|c|c|c|c|c|c|c|c|c|c|c|c|c|c|c|c|c|c|c|}
\hline & 1 & 2 & 3 & 4 & 5 & 6 & 7 & 8 & 9 & 10 & 11 & 12 & 13 & 14 & 15 & 16 & 17 & 18 & 19 & 20 & 21 & 22 \\
\hline 1 MF737083.1_UNVERIFIED:_Babesia_bovis_(current_study) & & & & & & & & & & & & & & & & & & & & & & \\
\hline 2 AB917246.1 Babesia bovis RAP-1 gene & 4.52 & & & & & & & & & & & & & & & & & & & & & \\
\hline 3 AF030056.2_Babesia_bovis_strain_S2P & 0.00 & 4.52 & & & & & & & & & & & & & & & & & & & & \\
\hline 4 AB845432.1_Babesia_bovis_RAP-1 gene & 4.43 & 0.00 & 4.43 & & & & & & & & & & & & & & & & & & & \\
\hline 5 AF027149.1_Babesia_bovis_phosphomannomutase & 4.22 & 4.12 & 4.22 & 4.03 & & & & & & & & & & & & & & & & & & \\
\hline 6 AF030059.1_Babesia_bovis_strain_T2b & 4.22 & 4.12 & 4.22 & 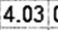 & 0.00 & & & & & & & & & & & & & & & & & \\
\hline 7 AF030055.1_Babesia_bovis_strain_R1A & 4.22 & 4.12 & 4.22 & 4.03 & 0.00 & 0.00 & & & & & & & & & & & & & & & & \\
\hline 8 AF030054.1_Babesia_bovis_strain_T2b & 0.00 & 4.52 & 0.00 & 4.43 & 4.22 & 4.22 & 4.22 & & & & & & & & & & & & & & & \\
\hline 9 AF030054.1_Babesia_bovis_strain & 0.00 & 4.52 & 0.00 & 4.43 & 4.22 & 4.22 & 4.22 & 0.00 & & & & & & & & & & & & & & \\
\hline 10 AF030053.1_Babesia_bovis_strain_S2P & 4.22 & 4.12 & 4.22 & 4.03 & 0.00 & 0.00 & 0.00 & 4.22 & 4.22 & & & & & & & & & & & & & \\
\hline 11 AF030061.2_Babesia_bovis_strain_Ur & 4.22 & 4.12 & 4.22 & 4.03 & 0.00 & 0.00 & 0.00 & 4.22 & 4.22 & 0.00 & & & & & & & & & & & & \\
\hline 12 KT312814.1_Babesia_bovis_isolate_YN2 & 4.43 & 0.01 & 4.43 & 0.00 & 4.03 & 4.03 & 4.03 & 4.43 & 4.43 & 4.034 & 4.03 & & & & & & & & & & & \\
\hline 13.KC964615.1_Babesia_bovis_clone_5M & 4.06 & 3.96 & 4.06 & 4.06 & 4.22 & 4.22 & 4.22 & 4.06 & 4.06 & 4.224 & 4.22 & 4.06 & & & & & & & & & & \\
\hline 14 JF279443.1_Babesia_bovis_isolate_Cuba & 4.43 & 0.01 & 4.43 & 0.00 & 4.03 & 4.03 & 4.03 & 4.43 & 4.43 & 4.034 & 4.03 & 0.01 & 4.06 & & & & & & & & & \\
\hline 15 FJ588011.1_Babesia_bovis_isolate_North & 4.22 & 4.12 & 4.22 & $4.03 \mathrm{C}$ & 0.00 & 0.00 & 0.00 & 4.22 & 4.22 & 0.000 & 0.00 & 4.03 & 4.224 & 4.03 & & & & & & & & \\
\hline 16 KT318580.1_Babesia_bovis_isolate_CQ & 4.43 & 0.01 & 4.43 & 0.01 & 4.03 & 4.03 & 4.03 & 4.43 & 4.43 & 4.034 & 4.03 & 0.00 & 4.060 & 0.01 & 4.03 & & & & & & & \\
\hline 17 KC894392.1_Babesia_bovis_isolate_KZN-B13 & 4.22 & 4.12 & 4.22 & 4.03 & 0.00 & 0.00 & 0.00 & 4.22 & 4.22 & 0.000 & 0.01 & 4.032 & 4.224 & 4.030 & & 4.03 & & & & & & \\
\hline 18 KT312807.1_Babesia_bovis_isolate_FJ2 & 4.43 & 0.02 & 4.43 & 0.01 & 4.034 & 4.03 & 4.03 & 4.43 & 4.43 & 4.034 & 4.03 & 0.01 & 4.060 & 0.024 & 4.030 & 0.004 & 4.03 & & & & & \\
\hline 19 KT312810.1_Babesia_bovis_isolate_HEN1 & 5.37 & 0.03 & 5.37 & 0.03 & 3.943 & 3.94 & 3.94 & 5.37 & 5.37 & 3.944 & 4.45 & 0.03 & 3.960 & 0.034 & 4.450 & 0.043 & 3.94 & 0.04 & & & & \\
\hline 20 LC006976.1_Babesia_bovis_rap-1 & 4.22 & 4.12 & 4.22 & 4.03 & 0.000 & 0.00 & 0.00 & 4.22 & 4.22 & 0.000 & 0.01 & 4.03 & 4.224 & 4.030 & 0.014 & 4.030 & 0.00 & 4.03 & 3.94 & & & \\
\hline $21 \mathrm{KX} 365053.1$ Babesia_bovis_BbAntioquia & 4.22 & 4.12 & 4.22 & 4.03 & 0.000 & 0.00 & 0.00 & 4.22 & 4.22 & 0.000 & 0.01 & 4.03 & 4.224 & 4.030 & 0.014 & 4.030 & 0.00 & 4.03 & 3.94 & 0.00 & & \\
\hline 22 KT318580.1_Babesia_bovis_isolate_CQ & 4.22 & 4.12 & 4.22 & 4.03 & 0.000 & 0.00 & 0.00 & 4.22 & 4.22 & 0.000 & 0.00 & 4.03 & 4.224 & 4.030 & 0.004 & 4.030 & 0.00 & 4.03 & 3.94 & 0.000 & 0.00 & \\
\hline $23 \mathrm{JX} 177355.1$ Babesia_bovis_strain_Placido_de_Castro & 5.52 & 0.06 & 5.52 & 0.05 & 3.593 & 3.59 & 3.59 & 5.525 & 5.52 & 3.593 & 3.61 & 0.06 & 4.060 & 0.053 & 3.610 & 0.063 & 3.59 & 0.07 & 0.083 & 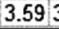 & 3.59 & 3.59 \\
\hline
\end{tabular}

Supplementary Figure-2: Pairwise genetic distance based on Rhoptry-Associated Protein-1 gene sequences of Babesia bovis detected in camel in Egypt and compared with other related species on GenBank.

\begin{tabular}{|c|c|c|c|c|c|c|c|c|c|c|c|c|c|c|c|c|c|c|c|c|c|c|c|}
\hline & 1 & 2 & 3 & 4 & 5 & 6 & 7 & 8 & 9 & 10 & 11 & 12 & 13 & 14 & 15 & 16 & 17 & 18 & 19 & 20 & 21 & 22 & 23 \\
\hline 1 MF737083.1_Babesia_bovis_(current_study) & & & & & & & & & & & & & & & & & & & & & & & \\
\hline 2 BAP47555.1_rhoptry-associated_protein_1_partial_Babesia_bovis & 0.00 & & & & & & & & & & & & & & & & & & & & & & \\
\hline 3 AAB84266.1_rhoptry_associated_protein-1_Babesia_bovis & 0.00 & 0.00 & & & & & & & & & & & & & & & & & & & & & \\
\hline 4 BAO50704.1_rhoptry-associated_protein_1_partial_Babesia_bovis & 0.00 & 0.00 & 0.00 & & & & & & & & & & & & & & & & & & & & \\
\hline 5 AAC27387.1_rhoptry_associated_protein-1_Babesia_bovis & 0.00 & 0.00 & 0.000 & 0.00 & & & & & & & & & & & & & & & & & & & \\
\hline 6 AAB84269.1_rhoptry_associated_protein-1_Babesia_bovis & 0.00 & 0.00 & 0.000 & 0.00 & 0.00 & & & & & & & & & & & & & & & & & & \\
\hline 7 AAB84265.1_rhoptry_associated_protein-1_Babesia_bovis & 0.00 & 0.00 & 0.000 & & 0.00 & 0.00 & & & & & & & & & & & & & & & & & \\
\hline 8 AAB84264.1_rhoptry_associated_protein-1_Babesia_bovis & 0.00 & 0.00 & 0.000 & 0.00 & 0.00 & $0.00 \mathrm{C}$ & 0.00 & & & & & & & & & & & & & & & & \\
\hline 9 AAB84264.1_rhoptry_associated_protein-1_Babesia_bovis(2) & 0.00 & 0.00 & 0.000 & 0.00 & 0.00 & 0.000 & 0.00 & 0.00 & & & & & & & & & & & & & & & \\
\hline 10 AAB84263.1_rhoptry_associated_protein-1_Babesia_bovis & 0.00 & 0.00 & 0.000 & 0.00 & 0.00 & 0.000 & 0.00 & 0.00 & 0.00 & & & & & & & & & & & & & & \\
\hline 11 AAB84271.1_rhoptry_associated_protein-1_Babesia_bovis & 0.01 & 0.01 & 0.010 & 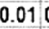 & 0.01 & 0.010 & 0.01 & 0.01 & 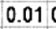 & 0.01 & & & & & & & & & & & & & \\
\hline 12 AKR16131.1_rhoptry-associated_protein_1a_partial_Babesia_bovis & 0.00 & 0.00 & 0.000 & 0.00 & 0.00 & 0.000 & 0.00 & 0.00 & 0.000 & 0.000 & 0.01 & & & & & & & & & & & & \\
\hline 13 AGT18676.1_rhoptry-associated_protein_1_partial_Babesia_bovis & 0.00 & 0.00 & 0.000 & 0.00 & 0.00 & 0.000 & 0.00 & 0.00 & 0.000 & 0.000 & 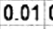 & 0.00 & & & & & & & & & & & \\
\hline 14 AEI52891.1_rhoptry-associated_protein_1_partial_Babesia_bovis & 0.01 & 0.01 & 0.010 & 0.01 & 0.01 & 0.010 & 0.01 & 0.01 & 0.010 & 0.010 & 0.00 & 0.01 & 0.01 & & & & & & & & & & \\
\hline 15 ACM44004_1_rhoptry_associated_protein_1_Babesia_bovis & 0.01 & 0.01 & 0.010 & 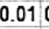 & 0.01 & 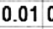 & 0.01 & 0.01 & 0.010 & 0.010 & 0.00 & 0.01 & 0.01 & 0.00 & & & & & & & & & \\
\hline 16 ALJ26466.1_rhoptry-associated_protein_1_partial_Babesia_bovis & 0.00 & 0.00 & 0.000 & 0.00 & 0.00 & 0.000 & 0.00 & 0.00 & 0.000 & 0.000 & 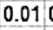 & 0.00 & 0.00 & 0.010 & 0.01 & & & & & & & & \\
\hline 17 AGU67927.1_rhoptry-associated_protein_1_partial_Babesia_bovis & 0.00 & 0.00 & 0.000 & 0.00 & 0.00 & 0.000 & 0.00 & 0.00 & 0.000 & 0.000 & 0.01 & 0.00 & 0.00 & 0.010 & & 0.00 & & & & & & & \\
\hline 18 AKR16124.1_rhoptry-associated_protein_1a_partial_Babesia_bovis & 0.00 & 0.00 & 0.000 & 0.00 & 0.00 & 0.000 & 0.00 & 0.00 & 0.000 & 0.000 & 0.01 & 0.00 & 0.00 & 0.010 & 0.010 & & 0.00 & & & & & & \\
\hline 19 AKR16127.1_rhoptry-associated_protein_1a_partial_Babesia_bovis & 0.01 & 0.01 & 0.010 & 0.01 & 0.01 & 0.010 & 0.01 & 0.01 & 0.010 & 0.010 & 0.03 & 0.01 & & 0.030 & 0.030 & & & 0.01 & & & & & \\
\hline 20 BAP81796.1_rhoptry-associated_protein_1_partial_Babesia_bovis & 0.00 & 0.00 & 0.000 & 0.00 & 0.00 & 0.000 & 0.00 & 0.00 & 0.000 & 0.000 & 0.01 & 0.00 & 0.00 & 0.010 & 0.010 & 0.000 & 0.00 & 0.00 & 0.01 & & & & \\
\hline 21 APP91268.1_rhoptry-associated_protein_1_partial_Babesia_bovis & 0.00 & 0.00 & 0.000 & 0.00 & 0.00 & 0.000 & 0.00 & 0.00 & 0.000 & 0.000 & 0.01 & 0.00 & 0.00 & 0.010 & 0.010 & 0.000 & 0.00 & 0.00 & & 0.00 & & & \\
\hline 22 BAW18785.1_rhoptry_associated_protein-1_partial_Babesia_bovis & 0.00 & 0.00 & 0.000 & 0.00 & 0.00 & 0.000 & 0.00 & 0.00 & 0.000 & 0.000 & 0.01 & 0.00 & 0.00 & 0.010 & 0.010 & & 0.00 & 0.00 & & & 0.00 & & \\
\hline 23 AFQ30755.1_hoptry-associated_1_partial_Eabesia_bovis & 0.13 & 0.13 & 0.130 & & 0.13 & 0.130 & 0.13 & 0.13 & 0.130 & 0.130 & 0.11 & 0.13 & 0.13 & 0.110 & 0.110 & & 0.13 & 0.13 & & & & 0.13 & \\
\hline 24 ACY76255.1_rhoptry_associated_protein-1_partial_Babesia_bovis & 0.01 & 0.01 & 0.010 & 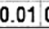 & 0.01 & 0.010 & 0.01 & 0.01 & 0.010 & 0.010 & 0.03 & 0.01 & 0.01 & 0.030 & 0.030 & 0.010 & 0.01 & 0.01 & 0.03 & 0.01 & 0.01 & 0.01 & 0.1 \\
\hline
\end{tabular}

Supplementary Figure-3: Pairwise genetic distance based on Rhoptry-Associated Protein-1 amino acid deduced sequences of Babesia bovis detected in camel in Egypt and compared with other related species on GenBank. 


\begin{tabular}{|c|c|c|c|c|c|c|c|c|c|c|c|c|c|c|}
\hline & 1 & 2 & 3 & 4 & 5 & 6 & 7 & 8 & 9 & 10 & 11 & 12 & 13 & 14 \\
\hline 1 MF737081_Trypansosma_evansi_(current_study) & & & & & & & & & & & & & & \\
\hline 2 LT220268.1_Trypanosoma_cruzi & 0.71 & & & & & & & & & & & & & \\
\hline 3 KF192994.1 Trypanosoma livingstonei & 0.77 & 0.66 & & & & & & & & & & & & \\
\hline 4 JN040992.1_Trypanosoma_erneyi & 0.74 & 0.54 & 0.15 & & & & & & & & & & & \\
\hline 5 JN040980.1_Trypanosoma_dionisii & 0.75 & 0.78 & 0.80 & 0.79 & & & & & & & & & & \\
\hline 6 AY773713.1 Trypanosoma theileri & 0.70 & 0.72 & 0.79 & 0.72 & 0.73 & & & & & & & & & \\
\hline 7 AY363165.1 Trypanosoma vivax & 0.71 & 0.72 & 0.79 & 0.74 & 0.73 & 0.71 & & & & & & & & \\
\hline 8 AY043356.1 Trypanosoma evotomys & 0.69 & 0.54 & 0.68 & 0.56 & 0.72 & 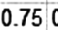 & 0.73 & & & & & & & \\
\hline 9 AY043355.1 Trypanosoma grosi & 0.69 & 0.54 & 0.68 & 0.56 & 0.72 & 0.750 & 0.73 & 0.00 & & & & & & \\
\hline 10 AY043354.1_Trypanosoma_microti & 0.69 & 0.54 & 0.68 & 0.56 & 0.72 & 0.750 & 0.73 & 0.00 & 0.00 & & & & & \\
\hline 11 AB362412.1_Trypanosoma_minasense & 0.73 & 0.69 & 0.71 & 0.71 & 0.68 & 0.750 & 0.73 & 0.17 & 0.17 & 0.17 & & & & \\
\hline 12 KY609969.1 Trypanosoma_equiperdum & 0.70 & 0.72 & 0.77 & 0.75 & 0.71 & $0.71 \mathrm{c}$ & 0.09 & 0.75 & 0.75 & 0.75 & 0.72 & & & \\
\hline 13 KT907061.1_Trypanosoma_teixeirae & 0.71 & 0.53 & 0.66 & 0.54 & 0.70 & 0.730 & 0.73 & 0.03 & 0.03 & 0.03 & & 0.75 & & \\
\hline 14 KT765860.1_Trypanosoma_herthameyeri & 0.71 & 0.54 & 0.66 & 0.54 & 0.71 & 0.720 & 0.73 & 0.03 & 0.03 & 0.03 & 0.18 & 0.75 & 0.03 & \\
\hline 15 KT368799.1_Trypanosoma_rangeli & 0.75 & 0.69 & 0.21 & 0.15 & 0.77 & 0.750 & 0.72 & 0.70 & 0.70 & 0.70 & 0.76 & 0.73 & 0.69 & 0.68 \\
\hline
\end{tabular}

Supplementary Figure-4: Pairwise genetic distance based on internal transcribed spacer 1 gene sequences of Trypanosoma evansi detected in camel in Egypt and compared with other related species on GenBank.

\section{Supplementary tables}

Table-S1: Babesia and Trypanosoma species used for genetic analysis in this study.

\begin{tabular}{|c|c|c|c|}
\hline \multirow[t]{2}{*}{ Babesia species } & \multicolumn{2}{|c|}{ Origin } & \multirow[t]{2}{*}{ Accession number } \\
\hline & Geographic & Biological & \\
\hline \multirow[t]{45}{*}{ B. bovis } & Uruguay & Cattle & AF030061 \\
\hline & North Brazil & Cattle & FJ588011.1 \\
\hline & China & Cattle & KT318580 \\
\hline & USA & Cattle & AF030053.1 \\
\hline & Argentina & Cattle & AF030055.1 \\
\hline & Texas USA & Cattle & AF030059.1 \\
\hline & Mexico & Cattle & AF027149.1 \\
\hline & South Africa & Bovine & KC894392.1 \\
\hline & Philippines & Cattle & LC006976.1 \\
\hline & Colombia & Cattle & KX365053.1 \\
\hline & Brazil & Bovine & JX177355.1 \\
\hline & China & Cattle & KT312807.1 \\
\hline & China & Cattle & KT318580.1 \\
\hline & China & Cattle & KT312814.1 \\
\hline & Cuba & Buffalo & JF279443.1 \\
\hline & Sri Lanka & Buffalo & AB845432.1 \\
\hline & Egypt & Cattle & $A B 917246.1$ \\
\hline & China & Cattle & KT312810.1 \\
\hline & Guinea-Bissau & Cattle & KC312810.1 \\
\hline & Brazil & Cattle & KC964615.1 \\
\hline & Egypt & Camel & MF737083.1 \\
\hline & Argentine & Cattle & AF030056.2 \\
\hline & USA & Cattle & AF030054.1 \\
\hline & Egypt & Cattle & BAP47555.1 \\
\hline & China & Cattle & ALJ26466.1 \\
\hline & USA & Cattle & AAB84269.1 \\
\hline & USA & Cattle & AAB84264.1 \\
\hline & Mexico & Cattle & AAC27387.1 \\
\hline & USA & Cattle & AAB84263.1 \\
\hline & China & Cattle & AKR16131.1 \\
\hline & Philippines & Cattle & BAP81796.1 \\
\hline & Argentine & Cattle & AAB84266.1 \\
\hline & China & Cattle & AKR16127.1 \\
\hline & Sri Lanka & Buffalo & BAO50704.1 \\
\hline & China & Cattle & AKR16124.1 \\
\hline & Brazil & Buffalo & AGT18676.1 \\
\hline & Colombia & Cattle & APP91268.1 \\
\hline & Argentine & Cattle & AAB84265.1 \\
\hline & USA & Cattle & AAB84264.1 \\
\hline & Portugal & Cattle & ACY76255.1 \\
\hline & Sri Lanka & Cattle & BAW 18785.1 \\
\hline & South Africa & Bovine & AGU67927.1 \\
\hline & Uruguay & Cattle & AAB84271.1 \\
\hline & Brazil & Cattle & ACM 44004.1 \\
\hline & Cuba & Buffalo & AEI52891.1 \\
\hline \multirow[t]{2}{*}{ B. bovis } & Brazil & Bovine & AFQ30755.1 \\
\hline & Germany & Vole & AB085191.1 \\
\hline
\end{tabular}

aGenBank accession numbers submitted by this study. B. bovis: Babesia bovis 
Table-S2: Trypanosoma species used for genetic analysis in this study.

\begin{tabular}{lllc}
\hline Trypanosoma species & \multicolumn{2}{c}{ Origin } & Accession number \\
\cline { 2 - 3 } & Geographic & Geographic & AY043354.1 \\
\hline Trypanosoma microti & Field vole & United Kingdom & AB362412.1 \\
Trypanosoma minasense & Squirrel-monkeys & Japan & AY043355.1 \\
Trypanosoma grosi & Wood mouse & United Kingdom & AY043356.1 \\
Trypanosoma evotomys & Bank vole & United Kingdom & KT765860.1 \\
Trypanosoma herthameyeri & Criolla frog & Brazil & KT907061.1 \\
Trypanosoma teixeirae & Red flying fox & Australia & LT220268.1 \\
Trypanosoma cruzi & ND & USA & KF192994.1 \\
Trypanosoma livingstonei & Roundleaf bat & Mozambique & KT368799.1 \\
Trypanosoma rangeli & bugs & Brazil & Mf737081.1 \\
T. evansi & Camel & Egypt & AY773713.1 \\
T. theileri & Cattle & Brazil & JN040980.1 \\
Trypanosoma dionisii & Free-tailed bat & Brazil & AY363165.1 \\
T. vivax & ND & South Africa & KY609969.1 \\
Trypanosoma equiperdum & Horse & & \\
\hline
\end{tabular}

aGenBank accession numbers submitted by this study. T. evansi=Trypanosoma evansi, T. theileri=Trypanosoma theileri, T. vivax $=$ Trypanosoma vivax 